Article

\title{
Legitimacy and Reciprocal Altruism in Donation-Based Crowdfunding: Evidence from India
}

\author{
Indu Khurana $\mathbb{D}$ \\ Department of Economics and Business, Hampden-Sydney College, 172 Via Sacra, \\ Hampden-Sydney, VA 23943, USA; ikhurana@hsc.edu
}

Citation: Khurana, Indu. 2021 Legitimacy and Reciprocal Altruism in Donation-Based Crowdfunding: Evidence from India. Journal of Risk and Financial Management 14: 194. https://doi.org/10.3390/jrfm14050194

Academic Editor: Douglas Cumming

Received: 10 March 2021

Accepted: 21 April 2021

Published: 25 April 2021

Publisher's Note: MDPI stays neutral with regard to jurisdictional claims in published maps and institutional affiliations.

Copyright: (C) 2021 by the author. Licensee MDPI, Basel, Switzerland. This article is an open access article distributed under the terms and conditions of the Creative Commons Attribution (CC BY) license (https:/ / creativecommons.org/licenses/by/ $4.0 /)$.

\begin{abstract}
The donation-based crowdfunding platforms witness a mix of different entities seeking funding for numerous campaigns, adding complexities in understanding the donor behavior and factors that motivate donation. This study builds upon the economic theory of charitable giving and examines the ethical dilemma that donors face during the selection process. Using the data from Ketto.org, the biggest crowdfunding platform in India, this paper investigates the rank-order preference of donors while making a selection across heterogeneous entities and campaigns. The results show that campaigns run by non-profit organizations registered with causes that qualify for a tax-deduction receive a higher level of funding. Donors then fund unregistered non-profit organizations, followed by campaigns run by individuals. Demonstrating legitimacy by using subtle cues, like tagging "with tax-benefit," motivates the donors to provide a higher amount of funding.
\end{abstract}

Keywords: crowdfunding; donation; altruism; legitimacy; India

\section{Introduction}

Crowdfunding has emerged as one of the dominant forms of financing new campaigns and has gained legitimacy across the globe as a worldwide phenomenon (Alegre and Moleskis 2019; Frydrych et al. 2014). Crowdfunding mobilizes large crowds through social media and online platforms to facilitate access to a large number of small donations. The broader contextual classification of crowdfunding depends on the type of return generated by the campaign and can, therefore, take various forms-reward, equity, debt, or donation (Belleflamme et al. 2014; Mollick 2014). So far, the research has advanced more in exploring patterns and factors that impact the success of reward-based crowdfunding platforms, including debt and equity models (Block et al. 2018; Bruton et al. 2015; Lim and Busenitz 2020; Ly and Mason 2012; Mohammadi and Shafi 2017; Moritz et al. 2015; Ralcheva and Roosenboom 2020; Thies et al. 2019). There is comparatively little work that examines which factors motivate donors to give money to donation-based crowdfunding models (Calic and Mosakowski 2016; Lehner and Nicholls 2014; Lehner 2013, 2014; Saxton and Wang 2014).

The question of what motivates people to support a social cause and specific entities has intrigued academics for decades (Andreoni 1989, 1990; Bekkers and Wiepking 2011; Vesterlund 2006). The literature on the economic theory of charitable giving provides evidence that donors consider various factors before making a charitable donation, including the credibility, mission, and accountability of the fund-seeking entity in the marketplace (Ottoni-Wilhelm et al. 2017; Vesterlund 2006). Rose-Ackerman (1996) examines the link between donor's motivation in charitable giving and the structure of the entity seeking funds and inquires, "does organizational form determine behavior, or does it provide a flexible structure that can accommodate a wide range of human objectives?" (p. 723). The author further mentions that entities seeking funding are all equal; however, one can identify the factors that impact donor motivation in different situations and also the rank ordering of preference that donors display. The structure of the entity seeking funding does influence what people fund and why. 
Furthermore, the economic theory of charitable giving also provides evidence that people regularly donate in an expectation of some benefit or an incentive in return. The donation made to charities for reasons other than pure humanitarian or altruistic motives is often known as reciprocal altruism. One of the most common examples of reciprocal altruism is the tax deduction that originates after giving funds to specific entities and specific causes (Rose-Ackerman 1996). Therefore, in the traditional charitable funding market, donors show preference to entities that demonstrate legitimacy and incentivize the very act of donation by reducing their overall tax bill (Van Slyke and Brooks 2005).

However, the literature on crowdfunding has so far not isolated the factors that impact donor motivation, primarily where various entities compete for the funding and simultaneously generate different levels of satisfaction for each donor. At any given point in time, there are multiple entities, like individuals or non-profit organizations (NPOs), seeking funding for numerous campaigns across the crowdfunding platforms. The presence of different entities across numerous campaigns adds complexities in understanding the donor behavior and the factors that motivate them (Salido-Andres et al. 2021).

This study, therefore, builds upon the economic theory of charitable giving and extends the framework of legitimacy and reciprocal altruism to examine the factors that impact the success of donation-based crowdfunding campaigns (Andreoni 1989, 1990; RoseAckerman 1996). The economic theory has been applied in a similar context to examine donor motivation across the microlending crowdfunding platforms (Gleasure and Feller 2016; Ly and Mason 2012). However, there is little work that extends the fundamentals of economic theory in donation-based crowdfunding, especially for developing economies (Li et al. 2018). Specifically, this study seeks answers to the two main questions-whether the legitimacy of the fund seeker plays a role in donation-based crowdfunding, if yes, how do fund seekers signal that legitimacy.

The study uses around 450 crowdfunding campaigns run on Ketto, one of India's largest crowdfunding websites. Ketto generates two signals on the campaign home page that indicate, first, if an individual or an NPO runs the campaign, and second if that specific NPO provides tax deduction benefit or not. For the second signal, Ketto runs a special banner on the home page of the campaign that says "Tax-Benefit" if the donor can claim a tax deduction (see Figure 1). These signals are then used to classify campaigns into three categories - campaigns run by (i) individuals, (ii) NPOs that offer a tax benefit, and (iii) NPOs that offer no tax benefit. Thereafter, multiple regression analysis is employed to ascertain who receives the highest amount of funding-individuals or NPOs; and then which type of NPOs get funding-NPOs that offer tax-benefit or NPOs that do not offer tax-benefit.

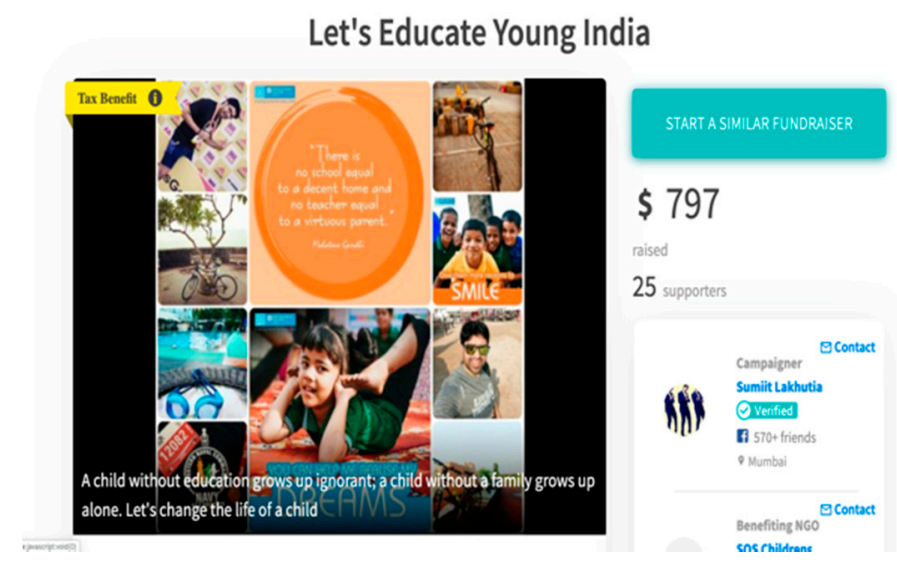

Figure 1. Screenshot of a campaign from Ketto. Source: https://www.ketto.org/fundraiser/ lovedandeducated (accessed on 8 March 2021).

The results show that donors reveal a rank ordering in their charitable campaign selection and funding level. First, legitimacy provides a competitive advantage, and 
campaigns run by NPOs receive a higher amount of funding than campaigns run by individuals. Second, within NPOs, campaigns that offer tax-deductibility receive the highest level of funding. Donors then fund NPOs that do not offer any tax-deduction benefit, followed by campaigns run by individuals. Therefore, NPOs that demonstrate legitimacy and signal it through causes that qualify for tax-deductibility raise more money.

The analysis offers three main insights on donation-based crowdfunding. First, there is a need to acknowledge campaign heterogeneity within a crowdfunding platform. Ignoring this differentiation can generate conflicting results in crowdfunding studies (Moleskis et al. 2019). NPOs that demonstrate legitimacy and reduce information asymmetries for the donors stand a better chance of receiving funding. At the same time, these NPOs jeopardize the likelihood of success for other campaigns. Second, there is an increasing need to create new regulations that monitor the crowdfunded income generated by NPOs that were not under government scrutiny earlier. Lastly, the majority of the studies on crowdfunding are focused on evaluating factors that affect campaign success in developed economies like the U.S. and Europe (Bagheri et al. 2019). However, crowdfunding in developing economies is very different from developed markets. With an increasing awareness about crowdfunding, there is a need to integrate and formalize the financial platforms that fuel charitable campaigns with new technologies. This formalization will help replicate successful models across countries, reduce ambiguities, and better synchronize donors and fund seekers.

The remainder of the paper is organized as follows. First, we provide a theoretical background on the economic theory of charitable giving and connect it with donationbased crowdfunding. Next, we discuss data and methodology, followed by a discussion of results. The overall conclusion follows at the end.

\section{Theoretical Background}

\subsection{The Economic Theory and the Issue of Legitimacy in Charitable Giving}

The traditional market for charitable funding is dominated by various structured organizations, like established charities (for-profit, not-for-profit), churches, community organizations, and universities, with each having its own set of missions and specific causes to promote (Clotfelter 1997). The variability in fund-seeking entities makes the process of selecting a legitimate and credible entity difficult for donors. The economic theory provides evidence that donors look for signals that indicate legitimacy in the entities while giving their money for charitable causes. Amongst various organizations, the likelihood of donors contributing to charitable NPOs is higher than donating to individuals and other organizations (Hansmann 1980; Rose-Ackerman 1996).

There are various reasons for this preference. First, NPOs address the inherent issue of information asymmetry in the framework of charitable giving to some extent by providing information about their working framework and presence as an entity through fundraising activities (Clotfelter 1997; Van Slyke and Brooks 2005; Weisbrod and Dominguez 1986). Information asymmetry leaves donors at a disadvantage because of incomplete information about the entity, quality of the campaign, and accountability after the donation. NPOs demonstrate signals such as efficiency, recognition, registration, visible address, and contact details (Spence 1973) that grant them higher legitimacy in securing funding from the donors (Venable et al. 2005). Second, the fact that NPOs do not distribute their earnings and instead utilize them for charitable causes gives them a competitive advantage in the presence of asymmetric information in the charitable giving framework. When donors have limited to no information about the quality of the campaign or outcome associated with it, a donation to NPOs assures the donor that the dollar amount donated will channel in the right direction (Webb et al. 2000). Third, donors are often passionate about the cause and ideas they support and not the mere act of giving. NPOs get another advantage by serving a variety of causes and not limited to a specific cause or a service (Rose-Ackerman 1996). Fourth, NPOs reduce the transaction costs associated with acquiring detailed information about the campaigns through their fundraising activities. 
Similar to traditional charitable giving, multiple signals in donation-based crowdfunding models force donors to identify legitimate entities and worthy causes for donation. A few crowdfunding websites (like Kiva.org) have hybrid platforms and allow both charitable campaigns and traditional entrepreneurial campaigns to seek funding on the same platform (Moleskis et al. 2019).

Donors' isolate signals from multiple campaigns that align with their mission and description of legitimacy. Organizations that can display credibility in their campaigns will attract donors that value legitimacy more than the cause of the campaign (Gandía 2011). Some of these signals include registration, access to the financial statements by the public, and online presence through a website. NPOs get a competitive advantage in the charitable funding market because of the capability to display such signals. Saxton and Wang (2014) provide evidence that NPOs leverage their workforce at their respective institutions to reduce the asymmetries further and creating awareness about the campaign. Pitschner and Pitschner-Finn (2014) differentiate between for-profit and not-for-profit crowdfunding projects and show that non-profits are more likely to reach their target goal. Likewise, Cumming et al. (2017) show that the clean technology (alternative energy) crowdfunding campaigns are also sensitive to the non-profit status (also see, Ahlers et al. 2015; Hörisch 2015). Additionally, Bento et al. (2019) show that allocating a percentage of profit to a charitable cause impacts the likelihood of the crowdfunding campaign. Therefore, in the presence of information asymmetries and the resulting incompetence to thoroughly analyze the campaign's quality, donors are more likely to donate to a cause that displays a higher level of overall legitimacy. This leads us to the first hypothesis:

Hypothesis 1. Donors will fund a higher amount to the campaigns run by non-profit organizations over campaigns run by individuals.

\subsection{Signalling Legitimacy}

The context-specific definition of crowdfunding differentiates the campaigns broadly into reward-based (including debt and equity markets) and non-reward-based (donation-driven markets) models. It is presumed that donors give money to the donation-based crowdfunding campaigns out of altruism without any expectation of the reward (Mollick 2014). However, people donate for various reasons-(i) pure altruism-where the sole aim is to increase the welfare of others, (ii) warm glow-an impure form of altruism where the focus is on the self-esteem and feeling good from the act of donation, (iii) reciprocal altruism-in addition to donation for a noble cause there is also an expectation of an incentive (Andreoni 1990).

The third form of donation is often classified as a rationalistic approach to altruism, where people often donate in expectation of a reward, like claiming a tax deduction on the amount of donation (for a detailed review, see, Bekkers and Wiepking 2011). Donations made exclusively to get a tax benefit is called reciprocal or subsidized altruism (André et al. 2017; Colombo 2001; Schroeder et al. 1995; Trivers 1971). People weigh their decisions and make rational choices. From the perspective of neoclassical economics, the behavior of altruism generates some positive benefit for the donor, and only pure altruism rarely motivates giving for philanthropic reasons (Andreoni 1990; Becker 1974).

Clotfelter (1997) mentions that two main features impact charitable giving in the United States. First is the tax-exempt status of the non-profit organizations, and second is the tax deduction that a donor can avail of on the contribution made to eligible entities. He further mentions that since the launch of the tax deductibility provision in 1917 in the U.S., individuals are more likely to donate if the contributions are tax-deductible. This result is consistent across various countries (Romney-Alexander 2002; Wiepking 2007; Wu et al. 2004). Morgan et al. (1979), in their study, show that about 43 percent of the respondents in their study donated because they could avail of a tax deduction. There are certain categories of donors like married households with children who are more likely to donate to decrease their tax burden (Van Slyke and Brooks 2005). In other words, promoting the 
incentive in the form of a tax deduction is likely to increase the contribution for the specific entity (Boatright et al. 2006; McGregor-Lowndes et al. 2006).

If economic rewards incentivize people to donate for a charitable cause, it would not be appropriate to classify donation-based crowdfunding into an outright no-reward category. In addition to the registered status of the NPOs, the literature on charitable giving provides evidence that tax-deduction on eligible donations also reflects legitimacy and motivates people to donate (Auten et al. 2002; Brown 1999; Morgan et al. 1979). However, the literature on crowdfunding has not examined the impact of signals that incentivize donations for social causes (Van Montfort et al. 2021). André et al. (2017) study reciprocal giving from the perspective of theory by Mauss (1923) and show that reward-based crowdfunding projects that have an element of reciprocal giving are more successful than other campaigns. If reward-based platforms respond to reciprocal altruism and contribute to the campaign's success, a similar logic can be extended to the donation-based crowdfunding platforms. The reward in donation-based crowdfunding is the legitimate signal of tax-deductibility that reduces the cost of the donation.

To account for such differences, we broadly classify the fundraising entities into three broad categories: individuals, organizations that provide tax benefit, and organizations that do provide tax benefit and hypothesize that:

Hypothesis 2. Donors will fund a higher amount to non-profit organizations that provide taxdeduction benefit over non-profit organizations that offer no tax-deduction benefit.

\section{Materials and Methods}

\subsection{Data}

The data for this study are collected from Ketto.org, the largest crowdfunding website in India. Ketto started operating in 2012 and has raised about 70 million USD (INR 500 crores) by the end of the year 2019 with about 2.4 million unique visitors, making it one of the most popular crowdfunding websites in India (Ketto.org 2019). Ketto was featured on the "top 100 Crowdfunding Blogs And Websites To Follow in 2019" (Feedspot 2019). Ketto allows both individuals and organizations to seek funding on their portal. The platform allows funding in children and adult health, education, community development, women empowerment, and others. Unlike the U.S.-based crowdfunding website Kickstarter, which follows the "all-or-nothing" model (Mollick 2014), Ketto does not penalize the campaigns for not reaching their target and instead allows them to keep the raised amount after accounting for transaction cost and processing fees. This omits any bias from not including failed campaigns or campaigns that did not meet their funding target in this study.

Ketto allows both individuals and NPOs to seek funding on the platform. NPOs in India can take three legal forms-trusts, societies, and Section 8 companies. There is no national law that governs trusts and societies; instead, there are monitored by state laws, like Public Trust Acts and Societies Registration Act. Section 8 companies, on the other hand, fall under the purview of the Indian Companies Act 1961, where the Central Government may issue a license to a limited or a private limited company that promotes commerce, art, science, or social welfare. An NPO must be organized for religious or charitable purposes and registered under the Indian Income Tax Act, 1961 (Section 12AA or Section 10 (23C)), to receive an income tax exemption (Income Tax, Department 2019) ${ }^{1}$. A donor, on the other hand, can claim a 50 percent tax deduction benefit under Section $80 \mathrm{G}$ of the Income Tax Act, 1961, on his/her income only if a contribution is made to a qualifying registered entity and a charitable cause.

One of the advantages for donors is that Ketto allows for such 80G tax benefit under the Income-tax Act, 1961, on donations made to eligible organizations on their platform (Crowdfunding 2019; Income Tax, Department 2019). The 80G tax-exempt certificate is generated instantaneously through Ketto's website. Figure 1 shows an example of the signal "Tax-Benefit" generated by Ketto on the top left corner if a donor receives the benefit of tax deduction. 


\subsection{Sample and Variable Construction}

Ketto's data management team provided the campaign-level data for all the campaigns that run in October and November 2019. The study uses information on the campaign's funding target, the number of donors, the total amount funded, and the geographical location of the campaign. Information on the fund seeker's social media connectivity, quality of the campaign, and the level of interaction with the donors during the campaign is collected from individual web links. The final sample size is 452 campaigns. The amount of funding received is used as a success metric (Calic and Mosakowski 2016; Gleasure and Feller 2016). The campaigns show a considerable variation in their funding targets, and the amount of funding received, leading to skewness in the data. To account for this skewness, we take a log of the total amount of funding raised by a campaign as the dependent variable. Following the hypotheses, explanatory variables are defined in Table 1.

Table 1. Variables.

\begin{tabular}{|c|c|}
\hline Variable & Description \\
\hline Funding Amount & Total amount of funding received. \\
\hline Funding Target & $\begin{array}{l}\text { Ketto does not follow a threshold model that a campaign has to } \\
\text { meet and allows the fund seeker to keep the total amount raised } \\
\text { through their website. Therefore, we include the log of the target } \\
\text { amount as an explanatory variable (Calic and Mosakowski 2016). }\end{array}$ \\
\hline Number of Donors & Number of people supporting the campaign. \\
\hline Duration of the campaign & $\begin{array}{l}\text { Ketto does not have any strict enforcement of days a campaign } \\
\text { can stay live on the website; therefore, we rely on the time and } \\
\text { date stamps generated by Ketto to capture the duration of } \\
\text { the campaign. }\end{array}$ \\
\hline Campaign Dialogue & $\begin{array}{l}\text { We identify two variables for campaign dialogue; first, the total } \\
\text { number of updates by the fund seeker during the campaign, and } \\
\text { second, the total number of comments by the public during the } \\
\text { campaign (Gleasure and Feller 2016). }\end{array}$ \\
\hline Campaign Quality & $\begin{array}{l}\text { Quality measures the effort put into the campaign. We, therefore, } \\
\text { include the number of images and total word count explaining } \\
\text { the campaign (Calic and Mosakowski 2016). }\end{array}$ \\
\hline Social Media Connectivity & $\begin{array}{l}\text { Various studies document the role of social media in the } \\
\text { crowdfunding initiative (Calic and Mosakowski 2016; } \\
\text { Datta et al. 2019; Mollick 2014). Therefore, we include a dummy } \\
\text { variable, which takes a value of " } 1 \text { " if the campaign is connected } \\
\text { with a Facebook account, " } 0 \text { " otherwise. }\end{array}$ \\
\hline Metropolitan & $\begin{array}{l}\text { This is a dummy variable that takes a value of " } 1 \text { " if the campaign } \\
\text { is run from a metropolitan area, " } 0 \text { " otherwise. }\end{array}$ \\
\hline Campaign motive & $\begin{array}{l}\text { This is a dummy variable that takes a value of " } 1 \text { " if a campaign } \\
\text { is run for self and " } 0 \text { " if a campaign is run on behalf of someone. }\end{array}$ \\
\hline Final Cause & $\begin{array}{l}\text { This variable is divided into children and adult health, education, } \\
\text { community development, women empowerment, and others. }\end{array}$ \\
\hline Parent-Cause & $\begin{array}{l}\text { This variable is measured by creating three dummy variables-(i) } \\
\text { Campaigns by individuals: takes a value of " } 1 \text { " if a campaign is } \\
\text { run by an individual and " } 0 \text { " otherwise, (ii) Campaigns by NPO } \\
\text { with tax benefit: takes a value of " } 1 \text { " if an NPO provides } \\
\text { tax-benefit and " } 0 \text { " otherwise, (iii) Campaigns by NPO without } \\
\text { tax benefit: takes a value of " } 1 \text { " if an NPO does not provide } \\
\text { tax-benefit and " } 0 \text { " otherwise. }\end{array}$ \\
\hline
\end{tabular}




\subsection{Methodology}

A semi-log linear regression model is used to estimate the following equation:

$$
\log f^{i}=\alpha+\beta d_{\text {parent-cause }}^{i}+\delta X^{i}+\varepsilon^{i},
$$

Here, $\log f^{i}$ is the amount of funding received for campaign $i, d_{\text {parent-cause }}^{i}$ is the variable that classifies the campaigns, first into individuals and NPOs to test hypothesis 1 , and then into campaigns run by individuals, NPOs with a tax benefit, and NPOs without tax benefit to test hypothesis $2 . X^{i}$ is the set of explanatory variables and $\varepsilon^{i}$ is the error term.

\section{Results}

\subsection{Descriptive Statistics}

The descriptive statistics and correlation matrix are provided in Tables 2 and 3, respectively. The minimum target amount is INR 2000, the maximum is INR 6,000,000, with an average target amount of INR 814,301. In contrast, the average amount of funding received was INR 144,502. This statistic shows that campaigns are setting a very high target on Ketto. Figure 2 shows that only about five percent of the projects meet their funding target. However, the results in the percentile show that the top goal campaigns are also the ones among which most funding is received (see Figure 3).

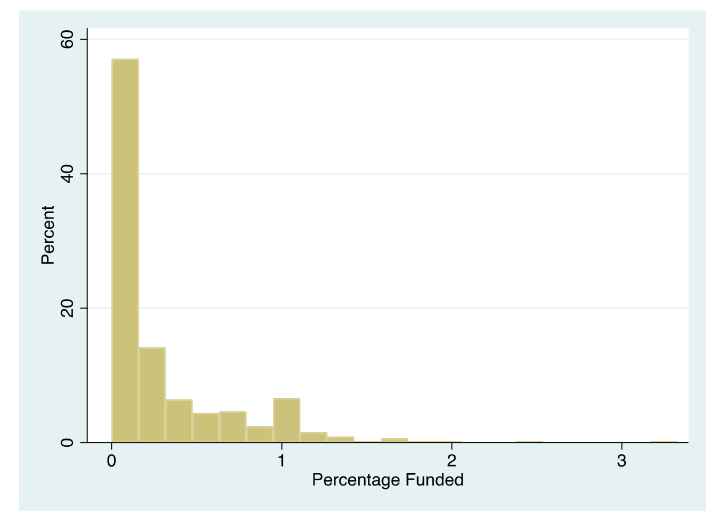

Figure 2. Histogram of funding density.

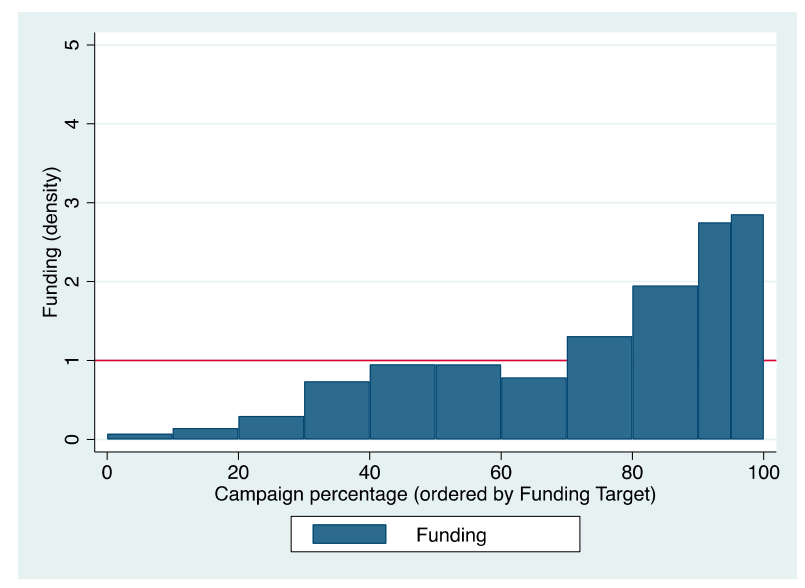

Figure 3. Funding amount received ordered by funding target. 
A campaign lasted for about 60 days and had about 21 donors on average. On average, donors posted three comments on the campaign, and the fund seeker posted close to two updates. The average number of images on a campaign was eight, with an average of 431 characters. Only one campaign had zero characters in the sample. About 60 percent of the campaigns are connected with Facebook, 68 percent are from major metropolitan areas in India, and 73 percent of the campaigns are run on behalf of someone. Around 41 percent of the campaigns are run by individuals, 33 percent by NPOs that provide tax-benefit, and 26 percent by the NPOs that do not provide tax-benefit. Since all the campaigns are social in nature, 23 percent of the campaigns are focused on children's health, 19 percent on adult health, 17 percent on children's education, five percent are related to women issues, and four percent on community development. Thirty-three percent of the cause deal with other broad issues like animal welfare, soldier well-being, festivals, and disaster relief.

Table 2. Descriptive statistics $(n=452)$.

\begin{tabular}{ccccc}
\hline Variables & Mean & Std. dev & Minimum & Maximum \\
\hline Funding Amount (in INR) & $64,347.33$ & $144,502.47$ & 1.00 & $1,491,991.90$ \\
Funding Target (in INR) & $461,465.53$ & $814,301.41$ & 2000.00 & $6,000,000.00$ \\
Number of Donors & 21.79 & 36.98 & 1.00 & 288.00 \\
Duration of the Campaign (days) & 69.45 & 52.81 & 2.00 & 289.00 \\
Number of comments by public & 3.69 & 7.02 & 0.00 & 47.00 \\
Updates during the campaign & 1.80 & 1.78 & 1.00 & 1.00 \\
Number of images & 7.95 & 6.54 & 0.00 & 20.00 \\
Word count & 431.98 & 285.20 & 0.00 & 2150.00 \\
Linked with Facebook & 0.60 & 0.49 & 0.00 & 1.00 \\
Metropolitan & 0.69 & 0.46 & 0.00 & 1.00 \\
Campaign for self & 0.27 & 0.44 & 0.00 & 1.00 \\
Children & 0.23 & 0.42 & 0.00 & 1.00 \\
Health & 0.19 & 0.39 & 0.00 & 1.00 \\
Education & 0.17 & 0.37 & 0.00 & 1.00 \\
Women & 0.05 & 0.22 & 0.00 & 1.00 \\
Other & 0.04 & 0.18 & 0.00 & 1.00 \\
Community development & 0.43 & 0.47 & 0.00 & 1.00 \\
Campaigns by individuals & 0.33 & 0.49 & 0.00 & 1.00 \\
Campaigns by NPO with tax benefit & 0.26 & 0.44 & 0.00 & 1.00 \\
\hline
\end{tabular}


Table 3. Correlation matrix.

\begin{tabular}{|c|c|c|c|c|c|c|c|c|c|c|c|c|c|c|}
\hline Variables & (1) & (2) & (3) & (4) & (5) & (6) & (7) & (8) & (9) & (10) & (11) & (12) & (13) & (14) \\
\hline (1) Funding Amount & 1.000 & & & & & & & & & & & & & \\
\hline (2) Funding Target & 0.272 & 1.000 & & & & & & & & & & & & \\
\hline (3) Number of Donors & 0.819 & 0.255 & 1.000 & & & & & & & & & & & \\
\hline (5) Number of comments by public & 0.818 & 0.237 & 0.888 & 0.230 & 1.000 & & & & & & & & & \\
\hline (6) Updates during the campaign & 0.271 & 0.080 & 0.267 & 0.211 & 0.327 & 1.000 & & & & & & & & \\
\hline (7) Number of images & 0.085 & 0.040 & 0.116 & 0.004 & 0.093 & 0.100 & 1.000 & & & & & & & \\
\hline (8) Word Count & 0.153 & -0.048 & 0.103 & 0.234 & 0.167 & 0.070 & 0.188 & 1.000 & & & & & & \\
\hline (10) Metropolitan & -0.058 & -0.222 & -0.075 & -0.032 & -0.093 & -0.115 & 0.026 & 0.066 & -0.157 & 1.000 & & & & \\
\hline (11) Campaign for self & 0.044 & 0.120 & 0.049 & 0.007 & 0.122 & 0.089 & -0.011 & 0.039 & 0.201 & -0.151 & 1.000 & & & \\
\hline (12) Campaigns by individuals & 0.129 & 0.345 & 0.152 & -0.038 & 0.152 & 0.178 & 0.091 & -0.152 & 0.243 & -0.328 & 0.350 & 1.000 & & \\
\hline (13) Campaigns with tax benefit & -0.002 & -0.183 & -0.067 & 0.083 & -0.062 & -0.145 & 0.001 & 0.241 & -0.187 & 0.218 & -0.326 & -0.581 & 1.000 & \\
\hline (14) Campaigns without tax benefit & -0.143 & -0.191 & -0.098 & -0.046 & -0.104 & -0.044 & -0.102 & -0.088 & -0.073 & 0.134 & -0.044 & -0.498 & -0.417 & 1.000 \\
\hline
\end{tabular}




\subsection{Findings}

The results of the regression models are reported in Table 4. Model 1 reports results for the log amount of funding received across individuals and NPOs. The coefficient for the variable campaign by individuals is negative and significant, highlighting that the campaigns run by NPOs irrespective of their type receive a higher level of funding, providing support for the first hypothesis and validating the presence of legitimacy. This result highlights the similarities between the factors that impact the traditional funding model and the modern internet-powered model for charitable campaigns. Both the models primarily share a common goal of securing funding for a social cause by understanding the legitimacy of the entity seeking funding.

To test the premise of the second hypothesis, we run another regression with a further categorization of NPOs that provide tax benefit and those that do not. For this, we use the NPOs that provide a tax benefit as the comparison group. The results presented in Model 2 indicate a negative and significant coefficient for both the variables, campaigns by individuals and NPO campaigns without any tax benefit. This highlights that NPOs that provide tax-benefit receive a higher level of funding when compared with other entities on the crowdfunding platform. The result aligns with the findings from the traditional charitable funding studies that have shown the positive impact of tax deduction to individuals on charitable giving for eligible organizations. Therefore, donors do factor in and integrate the tax-deduction savings when donating for altruistic reasons.

The results highlight increasing competition amongst charitable campaigns seeking funding from a diverse background of donors. The issue of legitimacy and information asymmetry forces donors to make their decisions based on signals that provide evidence of quality and assurance that money is spent for a good cause and also provides some benefit on their tax return. Charitable campaigns on crowdfunding platforms gain legitimacy from the donors in the form of a "crowd" and also from the fund seekers like a registered organization.

Other results align with the crowdfunding literature, like, a higher number of donors and images lead to more funding. Campaign dialogue between the donor and the public contributes positively to a higher level of funding. Coefficients for both the variables, the number of comments by the public, and the fund seeker's updates during the campaign are positive and significant. Social media connectivity and running a campaign from a metropolitan city have positive coefficients; however, these results are not significant.

Additionally, a higher target amount is positively related to the funding amount. This result does not agree with the research on reward-based crowdfunding platforms (Mollick 2014). This result could be motivated by the fact that the context is examined under a donation-based platform. To compare which cause receives higher funding, we use children's health as the comparison group. Similar to the results provided by other studies on donation-based crowdfunding, children's health receives higher funding than adult health and children's education (Ly and Mason 2012; Saxton and Wang 2014). Further, the amount of funding increases if a campaign is run on behalf of someone. Allison et al. (2015), in their study, emphasize a similar result and mention that a narrative of helping others can potentially attract more funding.

To overcome the bias in the results that could potentially come from the campaigns that received the highest amount of funding, we removed the top five percent of the campaigns with the highest funding received and repeated the regression analysis to test both the hypotheses. The results presented in Table 5 are robust after accounting for such potential bias and provide clear support for both the hypotheses. 
Table 4. Regression results for funding amount (log).

\begin{tabular}{|c|c|c|}
\hline & Model 1 & Model 2 \\
\hline Funding Target (log) & $\begin{array}{c}0.27^{* * *} \\
(4.12)\end{array}$ & $\begin{array}{c}0.26^{* * *} \\
(3.98)\end{array}$ \\
\hline Number of Donors & $\begin{array}{c}0.02 * * * \\
(4.47)\end{array}$ & $\begin{array}{c}0.02 * * * \\
(4.59)\end{array}$ \\
\hline Duration of the Campaign (log) & $\begin{array}{c}0.02 \\
(0.17)\end{array}$ & $\begin{array}{c}0.03 \\
(0.23)\end{array}$ \\
\hline Number of comments by public & $\begin{array}{l}0.05 * \\
(2.34)\end{array}$ & $\begin{array}{l}0.05 \text { * } \\
(2.18)\end{array}$ \\
\hline Updates during the campaign & $\begin{array}{l}0.09 * \\
(2.34)\end{array}$ & $\begin{array}{l}0.10 \text { * } \\
(2.43)\end{array}$ \\
\hline Number of images & $\begin{array}{l}0.03 * \\
(2.58)\end{array}$ & $\begin{array}{l}0.03 * * \\
(2.63)\end{array}$ \\
\hline Word count (log) & $\begin{array}{c}-0.19 \\
(-1.44)\end{array}$ & $\begin{array}{c}-0.24 \\
(-1.76)\end{array}$ \\
\hline Linked with Facebook & $\begin{array}{c}0.21 \\
(1.19)\end{array}$ & $\begin{array}{c}0.21 \\
(1.22)\end{array}$ \\
\hline Metropolitan & $\begin{array}{c}0.28 \\
(1.44)\end{array}$ & $\begin{array}{c}0.28 \\
(1.42)\end{array}$ \\
\hline Campaign for self & $\begin{array}{l}-0.77^{* *} \\
(-3.09)\end{array}$ & $\begin{array}{l}-0.73 * * \\
(-2.92)\end{array}$ \\
\hline Health & $\begin{array}{l}-0.78 * \\
(-2.25)\end{array}$ & $\begin{array}{l}-0.73 * \\
(-2.10)\end{array}$ \\
\hline Education & $\begin{array}{c}-0.98 * * * \\
(-3.87)\end{array}$ & $\begin{array}{l}-0.79 * * \\
(-3.06)\end{array}$ \\
\hline Women & $\begin{array}{c}0.24 \\
(0.86)\end{array}$ & $\begin{array}{c}0.23 \\
(0.79)\end{array}$ \\
\hline Community development & $\begin{array}{c}0.10 \\
(0.19)\end{array}$ & $\begin{array}{c}0.26 \\
(0.48)\end{array}$ \\
\hline Other & $\begin{array}{c}-0.21 \\
(-0.77)\end{array}$ & $\begin{array}{c}-0.09 \\
(-0.33)\end{array}$ \\
\hline Campaigns by individuals & $\begin{array}{l}-0.53 * \\
(-2.19)\end{array}$ & $\begin{array}{l}-0.77^{* *} \\
(-2.94)\end{array}$ \\
\hline Campaigns by NPO without tax benefit & & $\begin{array}{l}-0.48^{*} \\
(-2.40)\end{array}$ \\
\hline Constant & $\begin{array}{c}6.60 * * * \\
(6.02)\end{array}$ & $\begin{array}{c}7.04^{* * *} \\
(6.05)\end{array}$ \\
\hline$N$ & 451 & 451 \\
\hline
\end{tabular}

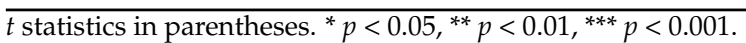


Table 5. Regression results for funding amount (log).

\begin{tabular}{|c|c|c|}
\hline & Model 3 & Model 4 \\
\hline Funding Target (log) & $\begin{array}{c}0.31^{* * *} \\
(4.70)\end{array}$ & $\begin{array}{c}0.30 * * * \\
(4.50)\end{array}$ \\
\hline Number of Donors & $\begin{array}{c}0.02^{* * *} \\
(4.51)\end{array}$ & $\begin{array}{c}0.02^{* * * *} \\
(4.62)\end{array}$ \\
\hline Duration of the Campaign (log) & $\begin{array}{c}0.09 \\
(0.66)\end{array}$ & $\begin{array}{c}0.10 \\
(0.73)\end{array}$ \\
\hline Number of comments by public & $\begin{array}{c}0.04 \\
(1.94)\end{array}$ & $\begin{array}{c}0.04 \\
(1.79)\end{array}$ \\
\hline Updates during the campaign & $\begin{array}{c}0.07 \\
(1.74)\end{array}$ & $\begin{array}{c}0.08 \\
(1.78)\end{array}$ \\
\hline Number of images & $\begin{array}{l}0.03^{*} \\
(2.23)\end{array}$ & $\begin{array}{l}0.03 * \\
(2.30)\end{array}$ \\
\hline Word count (log) & $\begin{array}{c}-0.19 \\
(-1.31)\end{array}$ & $\begin{array}{c}-0.23 \\
(-1.55)\end{array}$ \\
\hline Linked with Facebook & $\begin{array}{c}0.18 \\
(1.04)\end{array}$ & $\begin{array}{c}0.18 \\
(1.03)\end{array}$ \\
\hline Metropolitan & $\begin{array}{c}0.29 \\
(1.45)\end{array}$ & $\begin{array}{c}0.29 \\
(1.44)\end{array}$ \\
\hline Campaign for self & $\begin{array}{l}-0.79 * * \\
(-3.13)\end{array}$ & $\begin{array}{l}-0.76^{* *} \\
(-2.97)\end{array}$ \\
\hline Health & $\begin{array}{c}-0.62 \\
(-1.74)\end{array}$ & $\begin{array}{c}-0.59 \\
(-1.63)\end{array}$ \\
\hline Education & $\begin{array}{c}-1.06^{* * *} \\
(-4.07)\end{array}$ & $\begin{array}{l}-0.89 * * \\
(-3.28)\end{array}$ \\
\hline Women & $\begin{array}{c}0.39 \\
(1.41)\end{array}$ & $\begin{array}{c}0.38 \\
(1.31)\end{array}$ \\
\hline Community development & $\begin{array}{c}0.08 \\
(0.14)\end{array}$ & $\begin{array}{c}0.22 \\
(0.38)\end{array}$ \\
\hline Other & $\begin{array}{c}-0.14 \\
(-0.49)\end{array}$ & $\begin{array}{c}-0.04 \\
(-0.13)\end{array}$ \\
\hline Campaigns by individuals & $\begin{array}{l}-0.61^{*} \\
(-2.45)\end{array}$ & $\begin{array}{l}-0.81^{* *} \\
(-3.04)\end{array}$ \\
\hline Campaigns by NPO without tax benefit & & $\begin{array}{l}-0.42 * \\
(-2.02)\end{array}$ \\
\hline Constant & $\begin{array}{c}5.76^{* * *} \\
(5.03)\end{array}$ & $\begin{array}{c}6.15^{* * *} \\
(5.06)\end{array}$ \\
\hline$N$ & 425 & 425 \\
\hline
\end{tabular}

t statistics in parentheses. ${ }^{*} p<0.05,{ }^{* *} p<0.01,{ }^{* * *} p<0.001$.

\section{Discussion and Limitations}

Considering millions of dollars are raised worldwide on crowdfunding platforms, understanding donor motivation is becoming critical, especially for charitable campaigns. Donors collectively shape the financial landscape for charitable campaigns and direct the aid in specific sectors and to certain crowdfunding platforms that they believe have the most potential (Ly and Mason 2012). In their study on lending-based crowdfunding, Moysidou and Hausberg (2020) indicate that establishing trust is one of the most critical factors that motivate people to give money in financial settings where the due diligence process is not an option. Recognizing that donation-based crowdfunding falls on the spectrum where donors have little to no knowledge about the fund seeker, it becomes crucial to understand what trust is and how fund-seekers convey that trust to the donors.

Therefore, this study attempts to continue this discussion on establishing trust and legitimacy in a charitable framework and examine what motivates the donors to fund a campaign on a donation-based crowdfunding platform. The results show that campaigns run by registered NPOs with causes that qualify for a tax deduction receive a higher level of funding. Donors then fund unregistered non-profit organizations, followed by campaigns run by individuals. Demonstration of legitimacy through registration and use of subtle 
cues like tagging a campaign that provides a "tax-benefit" on the crowdfunding platform motivates the donors to fund such campaigns. The result is consistent with the literature on the economic theory of charitable giving and altruism.

The study is not without limitations. Since this study is based on an Indian crowdfunding platform, some results are specific to India. Neither social media linkage nor the word count was significant in the regression models. This result is in contrast to some of the studies that have been conducted in developed countries. One of the reasons could be less penetration of Facebook in India. Only 19 percent of Indian users have social media connectivity than 73 percent in the United States (Kemp 2017). Further, Indian donors, on the other hand, rely more on imagery rather than written word count. In a country where multilingualism is the norm (Sridhar 1996), written narratives in the English language can be perceived as barriers for fund seekers in modern crowdfunding platforms. Second, we only studied one crowdfunding platform. We suggest scholars extend this study and examine donor motivation in other crowdfunding platforms. Third, due to data limitations, we only measured donor motivation over a short duration of time. Future research can compare multiple crowdfunding platforms over multiple points in time.

Despite these differences, the results align with the economic theory of giving and have some policy implications for stakeholders experiencing, governing, and studying the phenomenon of crowdfunding. First, the study highlights the severe competition in donation-based crowdfunding models (Zhou and Ye 2019). Donation-based crowdfunding is different from reward-based crowdfunding models because donors do not receive anything tangible in return. Money that is donated bears a cost because it cannot be repurposed. Whether to donate or not depends on the information available on the crowdfunding platform. To attract funding, fund-seeking entities should aim to reduce the information asymmetries and transaction cost to access that information. Fund-seeking entities need to identify and evaluate the techniques that work in traditional funding models and then adapt them to the modern online platform. For NPOs, offering a tax-deduction is one such signal of legitimacy that attracts donors in a traditional funding market. NPOs should design the funding campaign that conveys such benefits and legitimacy on the crowdfunding platforms. Individuals and NPOs, who do not have such a competitive advantage, should carefully design their campaigns and build the dialogue with their donors.

Second, increasing technological awareness necessitates designing new regulations by the concerned government authorities that govern the crowdfunding platforms and the entities seeking funding on those platforms. Two parties make a significant revenue in this case, the crowdfunding platform and the NPOs; the governmental authorities need to set up statutes and regulations that keep NPOs accountable after the campaign has ended. This is especially an issue in developing countries where regulatory authorities are still responding to the crowdfunding boom (Bagheri et al. 2019; Li et al. 2018).

Finally, there is a need to incorporate rationality in the donor's selection process, even while examining charitable campaign funding. Belleflamme et al. (2014) note that profit-sharing and donation-based models of crowdfunding are quite similar. Their study refutes earlier beliefs that people donate out of altruistic behavior; instead, people donate in expectation of a positive incentive in the form of "community benefits." Donors foresee themselves as the consumers of the project they funded, and therefore incentive perspective works even in charitable giving. Colombo (2001) presents a similar perspective and mentions that "social scientists agree that much donative behavior results from "selfish" motives designed to maximize the donor's well-being in some way" (p. 24). Therefore, it is essential to incorporate donor rationality and monetary incentives in the donationbased crowdfunding model that provides an edge to the entities seeking funding and taking precedence in the donors' list of charitable giving. There is a need to reconsider a "no-reward" classification for donation-based crowdfunding models into a definition that incorporates monetary incentives in the model. 


\section{Conclusions}

To conclude, undoubtedly, the nexus between donors and fund seekers for charitable campaigns is growing exponentially. This arrangement demands context-specific research in developed and developing economies that explore the role of the welfare state, its limitations, and the success of alternative financing methods. The aim should be, first, to formalize the scattered market of crowdfunding for charitable campaigns, and second, to formulate policies that capitalize on the synergies generated from the donors across diverse platforms.

Funding: This research received no external funding.

Institutional Review Board Statement: Not applicable.

Informed Consent Statement: Not applicable.

Data Availability Statement: Data sharing not applicable.

Acknowledgments: The author would like to thank Ketto's team for providing access to the data.

Conflicts of Interest: The author declares no conflict of interest.

\section{Notes}

1 In the context of the United States, NPOs under section 501(C) 3 are tax-exempt and typically provide a tax-deduction benefit to the donors, whereas NPOs under section 501 (C) 4 offer no such tax-deduction benefits. Source-https: / / www.irs.gov/charities-non-profits / charitable-organizations / exemption-requirements-501c3-organizations (accessed on 8 March 2021).

\section{References}

Ahlers, Gerrit K. C., Douglas Cumming, Christina Günther, and Denis Schweizer. 2015. Signaling in Equity Crowdfunding. Entrepreneurship Theory and Practice 39: 955-80. [CrossRef]

Alegre, Inés, and Melina Moleskis. 2019. Beyond Financial Motivations in Crowdfunding: A Systematic Literature Review of Donations and Rewards. VOLUNTAS: International Journal of Voluntary and Nonprofit Organizations, 1-12. [CrossRef]

Allison, Thomas H., Blakley C. Davis, Jeremy C. Short, and Justin W. Webb. 2015. Crowdfunding in a prosocial microlending environment: Examining the role of intrinsic versus extrinsic cues. Entrepreneurship Theory and Practice 39: 53-73. [CrossRef]

André, Kévin, Sylvain Bureau, Arthur Gautier, and Olivier Rubel. 2017. Beyond the opposition between altruism and self-interest: Reciprocal giving in reward-based crowdfunding. Journal of Business Ethics 146: 313-32. [CrossRef]

Andreoni, James. 1989. Giving with impure altruism: Applications to charity and Ricardian equivalence. Journal of political Economy 97: 1447-58. [CrossRef]

Andreoni, James. 1990. Impure altruism and donations to public goods: A theory of warm-glow giving. The Economic Journal 100: 464-77. [CrossRef]

Auten, Gerald E., Holger Sieg, and Charles T. Clotfelter. 2002. Charitable giving, income, and taxes: An analysis of panel data. American Economic Review 92: 371-82. [CrossRef]

Bagheri, Afsaneh, Hasti Chitsazan, and Ashkan Ebrahimi. 2019. Crowdfunding motivations: A focus on donors' perspectives. Technological Forecasting and Social Change 146: 218-32. [CrossRef]

Becker, Gary S. 1974. A theory of social interactions. Journal of political economy 82: 1063-93. [CrossRef]

Bekkers, René, and Pamala Wiepking. 2011. A literature review of empirical studies of philanthropy: Eight mechanisms that drive charitable giving. Nonprofit and Voluntary Sector Quarterly 40: 924-73. [CrossRef]

Belleflamme, Paul, Thomas Lambert, and Armin Schwienbacher. 2014. Crowdfunding: Tapping the right crowd. Journal of Business Venturing 29: 585-609. [CrossRef]

Bento, Nuno, Gianfranco Gianfrate, and Marco Horst Thoni. 2019. Crowdfunding for sustainability ventures. Journal of Cleaner Production 237: 117751. [CrossRef]

Block, Jörn, Lars Hornuf, and Alexandra Moritz. 2018. Which updates during an equity crowdfunding campaign increase crowd participation? Small Business Economics 50: 3-27. [CrossRef]

Boatright, Robert G., Donald P. Green, and Michael J. Malbin. 2006. Does publicizing a tax credit for political contributions increase its use? Results from a randomized field experiment. American Politics Research 34: 563-82. [CrossRef]

Brown, Eleanor. 1999. Patterns and purposes of philanthropic giving. Philanthropy and the Nonprofit Sector in a Changing America 10: 212-30.

Bruton, Garry, Susanna Khavul, Donald Siegel, and Mike Wright. 2015. New financial alternatives in seeding entrepreneurship: Microfinance, crowdfunding, and peer-to-peer innovations. Entrepreneurship Theory and Practice 39: 9-26. [CrossRef] 
Calic, Goran, and Elaine Mosakowski. 2016. Kicking off social entrepreneurship: How a sustainability orientation influences crowdfunding success. Journal of Management Studies 53: 738-67. [CrossRef]

Clotfelter, Charles T. 1997. The economics of giving. In Giving Better, Giving Smarter. Working Papers of the National Commission on Philanthropy and Civic Renewal. Edited by Kenneth W. Dam and Bruno V. Manno. Washington, DC: National Commission on Philanthropy and Civic Renewal, pp. 31-55.

Colombo, John D. 2001. The Marketing of Philanthropy and the Charitable Contributions Deduction; Integrating Theories for the Deduction and Tax Exemption. Wake Forest Law Review 36: 657.

Crowdfunding, India. 2019. Crowdfunding India I Compare 10 Crowdfunding Platfrom in India. Available online: https://www. crowdfundingindia.org/ (accessed on 15 January 2020).

Cumming, Douglas J., Gael Leboeuf, and Armin Schwienbacher. 2017. Crowdfunding cleantech. Energy Economics 65: 292-303. [CrossRef]

Datta, Avimanyu, Arvin Sahaym, and Stoney Brooks. 2019. Unpacking the antecedents of crowdfunding campaign's success: The effects of social media and innovation orientation. Journal of Small Business Management 57: 462-88. [CrossRef]

Feedspot. 2019. Top 100 Crowdfunding Blogs \& Websites in 2019 | Best Crowdfunding Sites. Available online: http:/ /blog.feedspot. com/crowdfunding_blogs/ (accessed on 15 January 2020).

Frydrych, Denis, Adam J. Bock, Tony Kinder, and Benjamin Koeck. 2014. Exploring entrepreneurial legitimacy in reward-based crowdfunding. Venture Capital 16: 247-69. [CrossRef]

Gandía, Juan L. 2011. Internet disclosure by nonprofit organizations: Empirical evidence of nongovernmental organizations for development in Spain. Nonprofit and Voluntary Sector Quarterly 40: 57-78. [CrossRef]

Gleasure, Rob, and Joseph Feller. 2016. Does heart or head rule donor behaviors in charitable crowdfunding markets? International Journal of Electronic Commerce 20: 499-524. [CrossRef]

Hansmann, Henry B. 1980. The role of nonprofit enterprise. The Yale law journal 89: 835-901. [CrossRef]

Hörisch, Jacob. 2015. Crowdfunding for environmental ventures: An empirical analysis of the influence of environmental orientation on the success of crowdfunding initiatives. Journal of Cleaner Production 107: 636-45. [CrossRef]

Income Tax, Department. 2019. Tax Exempted Institutions. Available online: https://www.incometaxindia.gov.in/Pages/utilities/ exempted-institutions.aspx (accessed on 15 January 2020).

Kemp, Simon. 2017. India Overtakes the USA to Become Facebook's \#1 Country. Available online: https://thenextweb.com/ contributors /2017/07/13/india-overtakes-usa-become-facebooks-top-country/ (accessed on 5 May 2020).

Ketto.org. 2019. How Crowdfunding Works I What is Crowdfunding_Ketto. Available online: https://www.ketto.org/how_it_ works / how-fundraising-works.php (accessed on 12 December 2019).

Lehner, Othmar M., and Alex Nicholls. 2014. Social finance and crowdfunding for social enterprises: A public-private case study providing legitimacy and leverage. Venture Capital 16: 271-86. [CrossRef]

Lehner, Othmar M. 2013. Crowdfunding social ventures: A model and research agenda. Venture Capital 15: 289-311. [CrossRef]

Lehner, Othmar M. 2014. The formation and interplay of social capital in crowdfunded social ventures. Entrepreneurship $\mathcal{E}$ Regional Development 26: 478-99.

Li, Ya-Zheng, Tong-Liang He, Yi-Ran Song, Zheng Yang, and Rong-Ting Zhou. 2018. Factors impacting donors' intention to donate to charitable crowd-funding projects in China: A UTAUT-based model. Information, Communication E Society 21: 404-15.

Lim, JoAnne Yong-Kwan, and Lowell W. Busenitz. 2020. Evolving human capital of entrepreneurs in an equity crowdfunding era. Journal of Small Business Management 58: 106-29. [CrossRef]

Ly, Pierre, and Geri Mason. 2012. Individual preferences over development projects: Evidence from microlending on Kiva. VOLUNTAS: International Journal of Voluntary and Nonprofit Organizations 23: 1036-55. [CrossRef]

Mauss, Marcel. 1923. Essai sur le don. Forme et raison de L 'échange dans les sociétés Archaïques. L'Année Sociologique 1: 30-186.

McGregor-Lowndes, Myles, Cameron Newton, and Stephen Marsden. 2006. Did tax incentives play any part in increased giving? Australian Journal of Social Issues 41: 495-509. [CrossRef]

Mohammadi, Ali, and Kourosh Shafi. 2017. Gender differences in the contribution patterns of equity-crowdfunding investors. Small Business Economics 50: 275-87. [CrossRef]

Moleskis, Melina, Inés Alegre, and Miguel Angel Canela. 2019. Crowdfunding Entrepreneurial or Humanitarian Needs? The Influence of Signals and Biases on Decisions. Nonprofit and Voluntary Sector Quarterly 48: 552-71. [CrossRef]

Mollick, Ethan. 2014. The dynamics of crowdfunding: An exploratory study. Journal of Business Venturing 29: 1-16. [CrossRef]

Morgan, James N., Richard F. Dye, and Judith H. Hybels. 1979. Results from Two National Surveys of Philanthropic Activity. Michigan: Survey Research Center, Institute for Social Research, University of Michigan.

Moritz, Alexandra, Joern Block, and Eva Lutz. 2015. Investor communication in equity-based crowdfunding: A qualitative-empirical study. Qualitative Research in Financial Markets 7: 309-42. [CrossRef]

Moysidou, Krystallia, and J. Piet Hausberg. 2020. In crowdfunding we trust: A trust-building model in lending crowdfunding. Journal of Small Business Management 58: 511-43. [CrossRef]

Ottoni-Wilhelm, Mark, Lise Vesterlund, and Huan Xie. 2017. Why do people give? Testing pure and impure altruism. American Economic Review 107: 3617-33. [CrossRef]

Pitschner, Stefan, and Sebastian Pitschner-Finn. 2014. Non-profit differentials in crowd-based financing: Evidence from 50,000 campaigns. Economics Letters 123: 391-94. [CrossRef] 
Ralcheva, Aleksandrina, and Peter Roosenboom. 2020. Forecasting success in equity crowdfunding. Small Business Economics 55: 39-56. [CrossRef]

Romney-Alexander, Debbie. 2002. Payroll giving in the UK: Donor incentives and influences on giving behaviour. International Journal of Nonprofit and Voluntary Sector Marketing 7: 84-92. [CrossRef]

Rose-Ackerman, Susan. 1996. Altruism, nonprofits, and economic theory. Journal of Economic Literature 34: 701-28.

Salido-Andres, Noelia, Marta Rey-Garcia, Luis Ignacio Alvarez-Gonzalez, and Rodolfo Vazquez-Casielles. 2021. Mapping the Field of Donation-Based Crowdfunding for Charitable Causes: Systematic Review and Conceptual Framework. VOLUNTAS: International Journal of Voluntary and Nonprofit Organizations 32: 288-302. [CrossRef]

Saxton, Gregory D., and Lili Wang. 2014. The social network effect: The determinants of giving through social media. Nonprofit and Voluntary Sector Quarterly 43: 850-68. [CrossRef]

Schroeder, David A., Louis A. Penner, John F. Dovidio, and Jane A. Piliavin. 1995. The Psychology of Helping and Altruism: Problems and Puzzles. New York: McGraw-Hill.

Spence, Michael. 1973. Job Market Signaling. The Quarterly Journal of Economics 87: 355-74. [CrossRef]

Sridhar, Kamal K. 1996. Language in education: Minorities and multilingualism in India. International Review of Education 42: 327-47. [CrossRef]

Thies, Ferdinand, Alexander Huber, Carolin Bock, Alexander Benlian, and Sascha Kraus. 2019. Following the Crowd-Does Crowdfunding Affect Venture Capitalists' Selection of Entrepreneurial Ventures? Journal of Small Business Management 57: 1378-98. [CrossRef]

Trivers, Robert L. 1971. The evolution of reciprocal altruism. The Quarterly Review of Biology 46: 35-57. [CrossRef]

Van Montfort, Kees, Vinitha Siebers, and Frank Jan De Graaf. 2021. Civic Crowdfunding in Local Governments: Variables for Success in the Netherlands? Journal of Risk and Financial Management 14: 8. [CrossRef]

Van Slyke, David M., and Arthur C. Brooks. 2005. Why do people give? New evidence and strategies for nonprofit managers. The American Review of Public Administration 35: 199-222. [CrossRef]

Venable, Beverly T., Gregory M. Rose, Victoria D. Bush, and Faye W. Gilbert. 2005. The role of brand personality in charitable giving: An assessment and validation. Journal of the Academy of Marketing Science 33: 295-312. [CrossRef]

Vesterlund, Lise. 2006. Why do people give. The Nonprofit Sector: A Research Handbook 2: 168-90.

Webb, Deborah J., Corliss L. Green, and Thomas G. Brashear. 2000. Development and validation of scales to measure attitudes influencing monetary donations to charitable organizations. Journal of the Academy of Marketing Science 28: 299-309. [CrossRef]

Weisbrod, Burton A., and Nestor D. Dominguez. 1986. Demand for collective goods in private nonprofit markets: Can fundraising expenditures help overcome free-rider behavior? Journal of Public Economics 30: 83-96. [CrossRef]

Wiepking, Pamala. 2007. The philanthropic poor: In search of explanations for the relative generosity of lower income households. VOLUNTAS: International Journal of Voluntary and Nonprofit Organizations 18: 339. [CrossRef]

$\mathrm{Wu}$, Shih-Ying, Tsung Huang Jr., and An-Pang Kao. 2004. An analysis of the peer effects in charitable giving: The case of Taiwan. Journal of Family and Economic Issues 25: 483-505. [CrossRef]

Zhou, Huiquan, and Shihua Ye. 2019. Legitimacy, worthiness, and social network: An empirical study of the key factors influencing crowdfunding outcomes for nonprofit projects. VOLUNTAS: International Journal of Voluntary and Nonprofit Organizations 30: 849-64. [CrossRef] 